УДК 821.163.41.09"17" Обрадовић, Д. 821.112.2 Лесинг, Г. Е. https://doi.org/10.18485/msc50.2019.1.ch30

Миљан Мојашевић

\title{
О ПРЕВОЪЕЊУ ЈАКОБА ГРИМА НА СРПСКОХРВАТСКИ
}

\section{Пред његову двестагодишњицу}

У културноисторијском простору немачко-југословенских релација природно је да се са двестагодишњице рођења Јернеја Копитара (1980) упути поглед и према двестагодишњици рођења Јакоба Грима, јер она стоји пред нама на раздаљини од свега пет година (1985), само две године испред Караџићеве двестагодишњице (1987).

Лудвих Денеке издавач већ два међународна јубиларна зборника радова о браћи Грим ${ }^{1}$, и аутор прецизно и поуздано писане књиге Јакоб Грим и юегов брат Вилхелм², спремио је ове (1980) године и трећи зборник, који бисмо, са погледом на предстојећу 1985, могли можда пре сматрати - предјубиларним.

А почетком овог лета предложили су са Хумболтовог универзитета у Берлину: да и у оквиру партнерства између тог и Београдског универзитета заједнички размислимо о припреми Гримове двестагодишњице. Лако се слагати са таквим, захвалним и захвалности вредним подстицајима, али: ваља окупити људе за све то, пре свега стручњаке, а потом и оне које треба придобијати за струку.

Још немамо увид у то шта је од Јакоба Грима превођено на српскохрватски. Првенствено код Срба - јер ту је, наравно, тежиште и Гримовог интересовања за јужнословенску народну књижевност и културу, и, стога, тежиште и нашег проучавања Јакоба Грима. На то питање треба да одговори један магистарски рад о примању браће Грим на српскохр-

${ }^{1}$ Brüder Grimm Gedenken 1963. Gedenkschrift zur hundertsten Wiederkehr des Todestages von Jacob Grimm, herausgegeben von Ludwig Denecke und Ina-Maria Greverus, Marburg, Elwert Verlag, 1963, 610 стр., вел. $8^{0}$. - Brüder Grimm Gedenken, herausgegeben voh Ludwig Denecke, Marburg, Elwert Verlag, 1975, $304+8$ стр., вел. $8^{0}$.

${ }^{2}$ Ludwig Denecke, Jacob Grimm und sein Bruder Wilhelm, Stuttgart, Metzler 1971, 228 стр., $8^{0}$. 
ватском језичком подручју, ${ }^{3}$ почев од Магарашевићевог превода одломка из Гримовог предговора немачком преводу Караџићеве граматике у „Летопису Матице српске” 1825-1826, па до текстова који ће се, како смо обавештени, наћи у „Просветином” издању превода чланака о српској народној поезији, у избору Светозара Кољевића.

Писало се досад, и у вези са Гримом, углавном о томе како је, и зашто је тако бивало; треба и у тој сфери мењати и стално доприносити да бивање буде боље.

Вредело би размислити о томе: да се припреми и преведе један шири избор Гримових текстова, првенствено о књижевности, који би обухватио: прво, најбоље од есеја, сабраних у оних осам томова Гримових Краћux списа; друго: све његове чланке о српској народној књижевности, култури и српском језику, такође садржане у Краћим списима; треће: из његове преписке текстове који се односе на српску, односно српскохрватску књижевност и културу; четврто: сличне текстове и из његових великих дела, евентуално са контекстом у ком се дају примери на основу дела или казивања Вука Караџића; пето: Гримове метричке верзије превода српских народних песама. Пет година које стоје пред нама нису дуг рок за овакве послове.

Нешто слично, али веома минијатурно, дато је за школску употребу, у издању Завода за уџбенике СР Србије, иза стогодишњице Гримове и Караџићеве смрти ${ }^{4}$. Завод је тада издао, као школску лектиру, један избор из Гримових чланака, с тежиштем на његовим текстовима о српско-хрватској народној књижевности. Но тај школски избор је остављен у немачком тексту, ${ }^{5}$ а сада се предлаже један много шири, и не школски, у српскохрватском преводу. Био би то вредан и културноисторијски подухват ако бисмо такав избор могли дати, било истовремено, било у приближно исто време, и на српскохрватском, и на словеначком, и на македонском. Да је жив даровити, смели, многострано образовани преводилац Нибелуншке песме и Гетеовог Фауста на македонски, Душан Томовски, биле би реалније и наде у превод једног избора из Грима и на македонски.

О томе како је Грим преводио, и са српскохрватског, подоста је писано. Сад бисмо, обрнуто, а примера ради, да погледамо само неколико

3 Таква тема - Браћа Грим на српскохрватском језику - одобрена је маја 1979. године Љиљани Укмар да је обради као магистарски рад на Филолошком факултету Београдског универзитета.

4 Јакоб Грим, Избор из краћих списа, преписке и превода, Београд, Завод за издавање уџбеника СР Србије, 1965, 168 стр., $8^{0}$ (избор М. Мојашевића).

5 Уп. L. Denecke, нав. д., у нап. 2, стр. 185. 
појединости од мноштва оних које би ваљало имати у виду ако преводимо Гримове текстове на српскохрватски.

Верност, тачност, доследност основна су обележја и Гримовог превођења као што су основна обележја Гримовог, до крутости чврстог карактера. Мислимо, не само стога, да и њега треба преводити верно. Рећи ће неко: А како друкчије? - Па, олако и нетачно, да не кажемо: слободно. Треба и за верност и тачност у превођењу не само доста добре и истрајне воље, него и знања материје, и умења.

Гримови текстови о народној књижевности имају те још како и књижевнотеоријску, и књижевнопреводилачку, а не само књижевноисторијску тежину. Они имају и сталешки садржај и филолошку основу.

Да пођемо од појма Volk, народ. Шта је то заправо? Сви ми и о томе, као и о демократији, политици, филозофији, култури, цивилизацији, и много чему сличноме, имамо некакво знање, али већини нас биће тешко да прецизно омеђимо тај појам и кад га треба одредити као основни садржај у термину народна књижевност. Код питања смо: како би стварно требало преводити одавна устаљене, код Грима често употребљаване појмове Volksdichtung и Kunstdichtung? Није све свршено тиме што смо именицу Volk, у сложеници, превели придевом „народни”, и лако добили термине: народна књижевност, народна поезија, и сл. Има подоста прилика када исте, па и овакве сложенице ваља различито преводити. Некад је то стварно народна поезија, народна приповетка, народна песма, народна књижевност, а некад оно Volk у сложеници не значи да је то народно у смислу његове изворности, него: да је сачињено за народ.

Имали су Немци у 16. веку, веку др-а Мартина Лутера и протестантске револуције, веку Томаса Минцера и сељачке револуције, веку још једног од чудесних, титанских непослушника, др-а Јохана Фауста, повелик број тзв. Volksbücher, што ми преводимо са „народне књиге” уместо да кажемо: књиге за народ. Те су се књиге тада штампале на најгорој, најјевтинијој хартији. За народ. И на немачком језику има, наравно, доста песама чији аутори нису пали у „народну” анонимност, а те песме су се певале као народне. Међу њима и Гетеове. Али овај појам: народна књижевност, са разним варијацијама, намеће потребу још веће терминолошке прецизности код оног другог појма, према коме се он разграничава као опонентан. То су сложенице са основом Kunst уместо Volk: као Kunstpoesie, Kunstdichtung, Kunstmärchen. Ако ово Kunst преводимо, као што и преводимо, са „уметнички”, па кажемо: уметничка поезија, уметничка књижевност, уметничка бајка, као нешто што је друкчије од оног другог, онда ми оваквим преводом уствари поричемо уметничку вредност народне књижевности. А ми је већ одавна не поричемо, па 
тако превод и изворно значење иду у раскорак. За Јакоба Грима, и његове сличномишљенике, не постоји супроност између народне и уметничке, него: између народне и уметне, уметне у смислу - вештачке. Јер, пут ка том значењу је овај: природни, спонтани, неуки човек из села и народа, на једној; и школовани, цивилизовани човек, по правилу из замка и града, на другој страни. Онај у народу ствара спонтано своју поезију, и она се усмено и преноси, и мења, било да се дотерује или квари; а онај школовани је пише, подешава, већ према литерарној школи којој припада. Кад је тако, ваљало би преводити и код Грима оно Kunst у помињаним сложеницама са: уметни, а не са уметнички.

Свеједно да ли са одређеном намером или без ње, онај који је реч Kunstdichtung преводом „уметничка књижевност” супротставио појму Volksdichtung, вредновао је тиме народну књижевност као - говедарску, свињарску, или како се све онда могло о њој говорити у срединама Караџићевих противника. Било би свакако занимљиво поћи за историјом превођења тог појма на српскохрватски. На пример, оснивач и уредник Леmописа, Георгије Магарашевић, очигледно солидан зналац немачког језика преводи Гримово Bauern са „простаци”, уместо са „сељаци”. Сасвим негримовски! Управо је тај Bauer, тај сељак, тај гегула - природан, неизвештачен човек, Naturmensch. Он јесте прост, у смислу: једноставан, али то нипошто не значи и да је - простак. Простак је он за погоспођене, али не за Грима.

Уобичајено је и да се каже Гримов Ре ч н и к, као и Гримове Б а ј ке, а и Речник и Бајке су браће Грим, Гримових.

E, у Р е ч н и к у Гримових, под одредницом Kunstdichtung, стоји прецизна дефиниција: „kunstvolle dichtung ode rim gegensatz zur volkspoesie." У преводу: „уметничка књижевност или супротна народној поезији.” Ето на овој супротности између народне књижевности и уметничке, односно: и уметне и уметничког, највише смо се овде и задржали размишљајући о превођењу те речи на српскохрватски.

А под одредницом volksdichtung стоји и дефиниција „fürs volk bestimmte dichtung” - „књижевност намењена народу.” И поуздана констатација: „das wort immer mehr eingeschränkt auf die im ungelehrten volk lebende nicht individualistische dichtung”. У преводу: „реч све више сужавана на неиндивидуалистичку књижевност која живи у неуком народу”.

${ }^{6}$ О томе од писца овог реферата, Магарамевићев превод Гримовог предговора Каращићевој Граматици у Летопису 1825-1526. године. Научни састанак слависта у Вукове дане, 1975, V, 263 ид.

7 Deutsches Wörterbuch, von Jacob und Wilhelm Grimm, слово $\mathrm{K}_{2}$, стубац 2688.

${ }^{8}$ Исто, XII (1913), слово V, стубац 477-478. 
Преводиоцима са немачког биће често од користи да погледају у Речник Гримових.

Задржасмо се највише на превођењу речи речју, јер то сматрамо основним, иако зато ни мало не потцењујемо и оно што води ка ритму реченице као такође пресудног чиниоца у целокупној вредности верности, и садржајне и звуковне, једног превода.

Реченица, као већ мање-више развијен простор, са мисаоним и стилским изражајним особеностима једног писца, пресудан је показатељ његовог стила, што ће рећи и његове списатељске личности. Грим је изразита индивидуалност. Он је то до те мере, да је неко у своје време назвао његову Граматику - Граматиком. Ту индивидуалност треба преводилац да пронађе, и у речи и у реченици, и да је што верније пренесе. А у чему је та индивидуалност, та сума особености једног стила писања? Лако је питати, али са коликом сигурношћу је могуће на то одговорити? Не спада ли и то у оне силне гомиле недоартикулисаног знања, које нас изневери кад га треба пренети некоме у облику дефиниције?

Да одмах потражимо ослонац на примеру из Гримовог текста. У оном делу приказа треће књиге Караџићевих песама који је Караџић пренео, непреведен, у свој предговор, стоји нпр. реченица: „Nicht aus alten pergamentblättern hervorgesucht worden sind unsere serbischen lieder, sie sind alle aus dem warmen munde des volks aufgenommen, sie waren vielleicht vorher nie aufgeschrieben, sie sind in diesem sinne also nicht alt, werden aber wohl alt werden." Остављамо овде по страни размишљања зашто је Вук Караџић непреведене унео неколико страница Гримовог приказа на почетак свог предговора. У преводу тог текста у „Просветином", односно Недићевом издању Караџићевих дела та реченица гласи: „Нису наше српске народне песме извађене из пергаментских рукописа, него су оне покупљене са топлих усана народа: оне можда нису раније нигде записане, оне у том смислу нису дакле старе, али ће свакако доживети старост." ${ }^{10}$ Реч Mund преведена је речју „усне” уместо „уста” - да би деловала усклађеније са пергаментним рукописима, састављеним од листова. А требало ју је превести тачније, са „уста”, јер и Грим је могао употребити реч Lippen, усне, а није је употребио. Даље, мртвим листовима пергамента супротстављена су жива уста народа. Затим, те песме

9 Jacob Grimm, Kleinere Schriften (Band I-V herausgegeben von Karl Müllenhoff 1864-1871, Band VI-VIII herausgegeben von Eduard Ippel 1882-1890), Berlin - Dümmler 1869, IV, 199.

${ }_{10}$ Вук Стеф. Караџић, Српске народне пјесме, приредио Владан Недић, Београд, Просвета, 1969, I, 554. 
су по времену записивања сасвим младе, али ће, зато што вреде, трајати у векове. Ту антитетичност казивања треба преводилац да сачува у преводу. Али: ова реченица се комотно може поделити у четири, а с нешто мало преводилачке, односно редакторске слободе, и у читавих пет реченица. Таква преводиочева подела би упростила, али би и успорила Гримово казивање, и упропастила би ритам тог казивања. Преводилац ни то не треба да чини. Ова реченица је и на немачком доста опора, и није ни глатка ни гипка. Мислимо да треба пренети и ту опорост. И ту реченицу бисмо могли превести на више начина, па и да је примакнемо што обичнијем казивању, поготову ако бисмо хтели да се држимо лепо срочене мисли: да је најбољи онај превод који се не осећа као превод. Али: и карактер превода ваља чувати и по цену извесне тврдоће, јер истина има и естетску лепоту. Није свакоме све лепо што је глатко, поготову ако је глатко на штету истине. Ако реченица оригинала има извесну тврдоћу карактеристичну и за стил и за карактер писца, треба и њу пренети у превод. Нипошто не мислимо да је онаквим преводом Гримове реченице дато најбоље решење; али оно је свакако блиско и Гримовом поимању верног превођења.

Ни сам стил превода Гримове реченице није једноставан, караџићевски; он је изразито интелектуализован, гримовски. Но не пише ни Грим увек тако. Пише он понекад и упадљиво барокно, понекад класичарски јасно и једноставно, некад романтичарски понесено, већ према добу развитка, према предмету о ком пише, или према прилици за коју пише.

Гримовом цитираном реченицом фаворизује се језик обичног, једноставног човека. Исти онај језик који је и Лутер тражио међу обичним светом и када је преводио Библију. Близак је Грим Лутеру и када пише о превођењу, и када и сам преводи. А близак је Караџић у много чему, па и у томе, и Лутеру и Гриму, и када записује своја искуства са превођењем и када их своди у закључке. И зато нам веома недостаје Гримово име у веома корисној књизи Миодрага Сибиновића о историји и теорији превођења, ${ }^{11}$ јер та књига упућује и на добар избор немачких имена, претежно у контексту словенских, првенствено руских имена и примера.

Текстови на које се мисли да се одаберу и преведу на српскохрватски спадају, бар претежно, у књижевну критику и, по стилу писања, у научну, филолошко-историјску есејистику, есејистику у најбољем смислу речи, без икаквог призвука самозадовољне површности у њој.

11 Миодраг Сибиновић, Оригинал и превод, Увод у историју и теорију превођена, Београд, Привредна штампа, 1979, 191 стр., $8^{0}$. 
А шта је за српског, односно српскохрватског читаоца рецимо библијски, тацитовски, па ранкеовски, па гримовски стил, ако тај читалац не познаје стил оригинала? Можемо ли рећи: да је то онај стил у ком га том читаоцу понуди преводилац, када је то преводилац од формата, који или изграђује, односно има већ изграђен свој стил, какви су били преводиоци Библије, попут Лутера, наши Даничић и Караџић, или се наслања на већ постојећи стил какав је код нас народски јасни и језгровити Караџићев, како нам се чини да поступају: Веселин Чајкановић преводећи Тацитову Германију, или, претпостављамо, Стојан Новаковић или Огњан Радовић као преводиоци Ранкове Сриске револуције? Од Грима није преведено неко веће дело, које би и као такво било носилац гримовског стила на српскохрватском, нити је Грим и за краће ствари имао преводиоце који би га представили како ево замишљамо да га треба представити и на српскохрватском. Најбоље је градити тај стил на темељима верности оригиналу, верности управо у гримовском смислу.

Кад говоримо о верности превођења, ми тај принцип не сматрамо као супротност лепом, књижевном превођењу. Верност и лепота не би требало да искључују једна другу, те не би морало да буде никаквих дилема у избору између лепог и тачног превођења. Не мислимо ни ми, разуме се, на буквално превођење, него на верност: и мисаону, и емоционалну, и ритмичку, све до, коликогод је то могуће, и звуковне. Пример за то: Гетеов превод песме о Хасанагиници. Или: Шмаусов Горског вијениза.

Далеко смо од тога да превођење Грима отежавамо неким назови теоријским захтевима, али много држимо до оног знатно широког простора који преводиоцу остаје између механичке еквивалентности, почев нпр. од превођења бројева и термина, на једној, и селективно-креативне еквивалентности, на другој страни, да на том простору до краја развије изражајне могућности: и своје властите и језика на који преводи.

Гримова реченица је по правилу спонтана. То је реченица човека који много чита, много зна и брзо пише. Али: реченица која се не може брзо преводити. Грим прати ствар у њеној суштини, како је он види, а речи навиру и распоређују се у један стил иза кога стоји развијен систем мишљења. Преводилац ваља добро да напрегне свој интелектуални вид да што више тога уочи и пренесе. Преснимавати се ту не може: може се само мање или више примицати оригиналу или - што није добро - одмицати од њега у евентуалном, илузорном такмичењу са њим: да се он у нечему премаши. Не знамо у чему би се оригинал могао премашивати. 
ZU ÜBERSETZUNGEN VON JACOB GRIMMS SCHRIFTEN INS SERBOKROATISCHE Anläßlich der bevorstehenden 200-Jahresfeier seines Geburstags

Zusammenfassung

Aus der Sicht des diesjährigen (1980) Kopitar-Jubiläums wird auf die bevorstehende zweihundertste Wiederkehr des Geburstags von Jacob Grimm hingewiesen und eine ins Serbokroatische zu übersetzende Auswahl aus dessen Schriften vorgeschlagen und begründet. Dabei wird auf einige charakteristische Übersetzungsfragen und Schwierigkeiten aufmerksam gemacht. In den Bemühungen um die Wiedergabe von Grimm-Still in serbokroatischen Übersetzungen wird grundsätzlich treue Übersetzungsweise anempfohlen und der Standpunkt vertreten, daß auch beim Übersetzen Treue und Schönheit einander nicht ausschließen müssen. Ein Beispiel dafür: Goethes Übersetzung des „Klaggesangs”. Ein zweites: die Übersetzung des „Bergkranzes”, von Alois Schmaus. 